\title{
A BIOFILOSOFIA DOS GRAUS DO ORGÂNICO: ArNold GeHLen E A ONTOlogia de Nicolai HARTMANN
}

\section{[THE BIOPHILOSOPHY OF ORGANIC GRADES: ARNOLd GeHLEN AND THE Nicolai HaRtManN'S ONTOLOGY]}

Cleber Ranieri Ribas de Almeida Professor na Universidade Federal do Piaú Doutorando em Filosofia pela Universidade de São Paulo

Natal, v. 22, n. 40 Jan.-Abr. 2016, p. 127-168

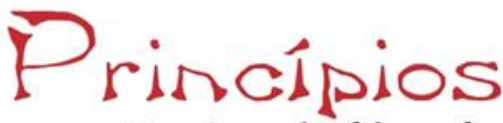

Revista de filosofia 
Resumo: O propósito deste artigo é investigar os fundamentos da antropobiologia de Arnold Gehlen de modo a demonstrar como o esquema darwiniano da evolução das espécies fora aí substituído pela biofilosofia dos graus do orgânico de Nicolai Hartmann. Esta substituição permitiu que Gehlen distinguisse claramente entre as Leis Estruturais da Constituição Humana (LECH) e as Operações Humanas (OPHU). Segundo Gehlen, a ação conjunta (handlung zuzammen) entre estruturas e operações humanas forma um circuito inconsútil no qual as carências vitais do homem (mängelwesen) são supridas mediante ações de descarga. A observação fenomenológica das leis de descarga (entlastungsgefahren) se dá na fabricação do mundo (Welt). Malgrado seus notáveis progressos no que diz respeito à explicação não-zoológica do homem, o modelo gehleniano reduziu a percepção fenomenológica do humano a uma mecânica de operações e estruturas. A substituição do esquema darwiniano pela ontologia de Nicolai Hartmann nos provê uma explicação holística e singular do homem, porém, sob pena da redução mecânica das operações simbólicas e numênicas.

Palavras-chave: Antropologia Filosófica; Filosofia da Biologia; Arnold Gehlen; Graus do orgânico; Ontologia de Nicolai Hartmann.

Abstract: This paper shall investigate the foundations of Arnold Gehlen's anthropology in order to demonstrate how the Darwin's Evolutionary Scheme was then replaced by Nicolai Hartmann's biophilosophy of organic grades. This replacement allowed Gehlen distinguishes between the Structural Laws of Human Constitution and the Human Operations (HUOP). According to Gehlen, the action (handlung zuzammen) between human structures and operations forms a circuit in which that the man's vital deficiencies (mängelwesen) are supplied by reliefs. The principle of relief (Entlastungsgefahren) can be observed through action of building cultural and symbolic world (Welt). This model, despite its remarkable progress concerning non-zoological explanation of human being reduced phenomenological perception of the human to the mechanical operations. In this logic, replacing the Darwinian scheme by Nicolai Hartmann's ontology provides us with a holistic and unique explanation of man, however, under penalty of mechanical reduction of symbolic and noumenal operations.

Keywords: Philosophical Anthropology; Philosophy of Biology; Arnold Gehlen; Organic grade; Nicolai Hartmann's ontology. 
O livro Der Mensch: seine Natur und seine Stellung in der Welt $(O$ Homem: sua natureza e seu lugar no mundo), de Arnold Gehlen, foi publicado pela primeira vez em 1940, portanto, doze anos depois da publicação dos livros de Max Scheler, Die Stellung des Menschen im Kosmos (A posição do Homem no Cosmos), e Helmuth Plessner, Die Stufen des Organischen und der Mensch (Os graus do orgânico e o Homem), ambos publicados em 1928. Como sabemos, estas três obras passaram a compor o cânone do que denominamos hoje por antropologia filosófica. Gehlen fora aluno de Scheler e Nicolai Hartmann na Universidade de Colônia, porém, sua tese de doutoramento, datada de 1927, fora dedicada à interpretação da obra de seu orientador, Hans Driesch, com o título Zur Theorie der Setzung und des stzungshaften Wissens bei Driesch (Sobre a teoria da posição e do saber posicional em Driesch). O caminho aberto por Max Scheler e a revisitação crítica de Helmuth Plessner ao programa de pesquisa da antropologia filosófica deram visibilidade a este problema filosófico. O interesse público aumentou com a publicação de Der Mensch e suas mais de dez edições (Arlt, 2008, p. 159196) num curto intervalo de tempo.

O objetivo geral de Gehlen era propor uma nova autointerpretação da origem e da essência do homem de maneira que ambas não derivassem de uma zoologia evolucionista dos símios, tampouco de uma concepção religiosa, deísta ou metafísica. Gehlen elegera a autoimagem "darwininista" e zoológica do homem como sua principal adversária. Rejeitava veementemente a fórmula evolucionista que estuda o homem a partir dos critérios científicos de uma zoologia geral. Tal rejeição devia-se, como veremos, à defesa de uma posição especial do homem na ordem da physis. Ademais, a imagem constituída pelas ciências empírico-analíticas era, em seu julgamento, demasiado fragmentária, uma vez que formava um mosaico de múltiplas ciências particulares nas quais o homem era concebido de forma dissecada. O projeto do autor seria "conceber o homem como um objeto inequívoco para uma antropologia geral" (Gehlen, 1980, p. 12), isto é, "uma antropologia indepen- 
dente que falasse de um ser humano independente" (ibidem, p. 14). Gehlen, portanto, negava-se a constituir sua antropologia filosófica a partir da assimilação passiva das antropologias científicas particulares.

Para ele, tanto as ciências particulares do homem quanto a antropologia filosófica falharam ao tentar descrever o homem como ser holístico, ou seja, como ser simultaneamente anímico e corpóreo. As tentativas de Plessner e Scheler quanto a explicar o caráter espiritual em conjunção ao caráter corporal do homem, isto é, a fórmula geral da unidade corpo-alma-espírito, seria demasiado abstrata e expressaria apenas o rechaço ao dualismo cartesiano. Ademais, a busca por características ou propriedades humanas em separado, ao enfatizar a linguagem ou o uso das mãos, por exemplo, como peculiaridades do homem, apenas reforçava o caráter fragmentário das antropologias particulares.

Embora sejam "fórmulas" ou "imagens" heterogêneas, tanto a ciência quanto a religião partem de um pressuposto comum, qual seja: "que o homem não pode ser compreendido desde si; que só pode descrever-se ou interpretar-se com categorias extra-humanas" (Gehlen, 1980, p. 10). Ambas são fórmulas que derivam a autoimagem do homem, ora da imagem de Deus (imago Dei), ora de uma ramificação zoológico-evolutiva dos símios e hominídeos. Aí reside o propósito mais ambicioso do autor: desenvolver uma concepção da essência do homem que se valha de conceitos específicos e só aplicáveis a este objeto. Para Gehlen, o ser humano é um projeto único da natureza, um "desenho especial" (ibidem, p. 16), um ser de exceção que contradiz toda a lei orgânica do mundo natural. Numa palavra, o homem é um objeto singular de investigação e, como tal, demanda um método especial: "a ciência da totalidade do homem" (ibidem, p. 18).

Somente a partir desta ciência holística é que será possível desenvolver uma antropologia filosófica da singularidade do homem. Cabe-nos aqui definir o que se denomina por antropologia filosófica, a fim de evitar a mixórdia com as filosofias do homem, 
com os humanismos ou com a analítica existencial do ser. Definese por antropologia filosófica exclusivamente aquela antropologia que busca incorporar os avanços das denominadas ciências do homem - biologia humana, paleoantropologia, fisiologia, anatomia, neurologia, arqueologia, etologia e psicologia, entre outras ao estudo filosófico do humano, de modo que, a partir destes elementos científicos, se possam enfeixar os fatores que concedem unidade à espécie. Seria, portanto, um problema filosófico cuja solução demandaria um diálogo permanente com as ciências empíricas do homem no intuito de produzir uma síntese fenomenológica destas ciências, isto é, buscar uma resposta acerca da unidade do humano (Fischer, 2009, p. 9-94). Odo Marquard a define em contraposição à filosofia da história ao assinalar que ela:

se torna possível mediante o abandono da metafísica da escola tradicional e das ciências matemáticas da natureza, quer dizer, mediante uma "reviravolta ao mundo da vida", a qual se torna fundamental mediante o "retorno ao mundo da natureza", quer dizer, mediante a resignação da filosofia da história. (Marquard, 2007, p. 149)

Portanto, não há antropologia filosófica sem uma filosofia da natureza, nem toda filosofia do ser humano é uma antropologia filosófica.

O propósito deste artigo é investigar como a biofilosofia dos graus do orgânico de Nicolai Hartmann fora incorporada aos fundamentos da antropobiologia gehleneana de modo que exercesse a função de substituta ao esquema darwiniano da evolução das espécies. Esta substituição conduziu Gehlen a uma aporia: a impossibilidade científica de desvelar a passagem do inorgânico para o orgânico. Como afirmou Habermas (1975, p.92), Gehlen move-se inteiramente sobre a linha de análise categorial de Hartmann, ou seja, ele mobiliza a ontologia hartmanneana não apenas como fundamento necessário para comprovar a lei da descarga, mas também como fundamento geral de sua antropobiologia. Nesta lógica, Gehlen aplica à risca a tese hartman- 
neana, segundo a qual "o homem contém em si todos os estratos ontológicos, e seria uma abstração vazia considerá-lo unilateralmente como se tratasse somente de um ser espiritual" (Hartmann, 1954, p. 134). Quer dizer, o homem é o único ser que agrega em si as quatro camadas do ser, quais sejam (da superior à inferior): o espírito, o psíquico, o orgânico e o inorgânico. Para demonstrar como Gehlen se apropria da ontologia hartmanneana, faremos o seguinte percurso: (i) demonstraremos como a ciência da totalidade do homem proposta por Gehlen é inconciliável com o esquema dos graus do orgânico bem como às poéticas do homem comuns às filosofias do espírito. Para compreender a singularidade do homem enquanto projeto único da natureza, Gehlen proporá uma antropologia filosófica contraposta a de Max Scheler, cujo propósito era superar o dualismo cartesiano, o que se provou impraticável, tendo em vista que Scheler reproduziu os princípios ontológicos da biologia darwinista. Mais do que isso, Gehlen, por entender que o comportamento instintivo e o inteligente são mutuamente excludentes, recorrerá à etologia de Konrad Lorenz, ao vitalismo bergsoniano e à crítica de F. J. J. Buytendijk à Darwin para provar tal contradição; (ii) a aplicação do programa de pesquisa gehleneano postulará que o homem só pode ser integralmente compreendido pela ação conjunta (Handlung Zuzammen) das Leis Estruturais da Constituição Humana (LECH) em relação às Operações Humanas (OPHU); (iii) esta correlação só poderá ser resolvida mediante uma investigação das leis pertinentes às ações de descarga (Entlastungsgefahren). Para concluir, arguiremos que o caráter transoperacional e transorgânico da categoria da descarga só pode explicar os mecanismos das operações humanas, porém, não nos fornece explicações plausíveis para as questões relativas à instituição da violência e ao simbolismo do sagrado. Trata-se, portanto, de uma mecânica do homem. 


\section{O esquema dos graus do orgânico: \\ a crítica a Konrad Lorenz e Max Scheler}

Gehlen $^{1}$ concentra seus esforços na crítica ao denominado "esquema dos graus do orgânico" proposto por Max Scheler e, mutatis mutandis, reproduzido por Helmuth Plessner. Como sabemos, o esquema de Scheler divide-se em quatro fases que se sucedem necessariamente: (i) o impulso afetivo; (ii) o instinto; (iii) a memória associativa; (iv) a inteligência prática. A partir deste esquema, Scheler sente-se habilitado a apresentar-nos uma distinção plausível entre o homem e o animal, o que ocorrerá no segundo capítulo de Die Stellung, intitulado "A diferença essencial entre o homem e o animal". Gehlen recusa tal esquema porque a ordem sucessiva que o caracteriza replica os erros do evolucionismo, sobretudo no que diz respeito à definição do conceito de instinto e no papel exercido pela inteligência prática na distinção entre o homem e o animal.

Na visão crítica de Gehlen, Max Scheler entendia que a partir do comportamento instintivo - o qual se caracterizaria por ter um ritmo determinado, pleno de sentido, não adquirido e que servisse à espécie (Scheler, 2003) - surgiria tanto o comportamento habitual quanto o inteligente. $\mathrm{O}$ instinto seria a faculdade mais primitiva que daria impulso à conduta habitual, a qual poderia ser alterada de modo dirigido e conforme as circunstâncias do ambiente, a fim de melhor servir à vida de um dado ser vivo. Para que tal mudança ocorra, este ser vivo se valeria das experiências anteriores e do número de tentativas e erros dados pela vivência. De fato, Scheler afirmara que sempre que um animal retivesse movimentos adquiridos mediante tentativas que tivessem êxito e os exercitasse formar-se-ia um hábito. A memória associativa estaria também a serviço desta faculdade de reaprendizado ou adaptação, assim

${ }^{1}$ Gehlen, 1993. As traduções em espanhol (de Fernando-Carlos de Vevia Romero) e em inglês (de Clare McMillan e Karl Pillemer) também serão utilizadas para nos auxiliar nas traduções de excertos e citações. Todas as traduções do livro de Gehlen são feitas por mim. 
como a imitação de atos e movimentos intraespécies. Em resumo, Scheler pressupõe que os seres vivos dotados de faculdades cognitivas como capacidade de exercício (tentativa e erro), hábito, imitação e memória associativa são significativamente distintos daqueles que se movem tão somente pelo impulso afetivo-instintivo (as plantas). Assim surgem as novas formas físicas na natureza, ou seja, como desdobramento necessário dos perigos impostos pelo ambiente o qual cria situações não típicas e não específicas, de modo que a subsistência de um dado ser vivo dependa do uso de uma certa inteligência prática e da capacidade de solucionar tais novas situações. O ser vivo passa, em tais condições, a exercer uma conduta análoga nova a qual requer a antecipação, a planificação, a imaginação e a criação de um novo modus operandi em favor da vida.

Dado que os símios superiores são espécies dotadas de tais atributos e, portanto, não são seres primitivos meramente instintivos, pergunta-se: qual seria, ipso facto, a diferença essencial entre o homem e os animais, ou melhor, entre o homem e os símios? A resposta de Scheler é a de que o homem não possui apenas inteligência prática ou memória associativa, mas, possui uma capacidade de ideação a que denominamos Espírito. Por Espírito define-se o princípio anímico singular ao homem cuja afirmação implique necessariamente numa recusa ascética às necessidades orgânico-corporais. O Espírito, portanto, está contraposto à vida enquanto manifestação puramente orgânico-corpórea, isto é, enquanto movimento espontâneo da ação de um ser vivo em direção à sua própria sobrevivência. $O$ Espírito é a força anímica que diz "não" a toda pulsão corpórea e estabelece para si mesmo um horizonte de ideação para o qual se move. Portanto, o Espírito se afirma enquanto força não-vital, relação puramente transcendente do homem com o Eterno e o Absoluto. Está claro que para Scheler, a distinção entre o homem e o animal seria dada pelo Espírito, e este se definiria como uma negação da pulsão vital que iguala o homem aos demais animais. Aí reside "o princípio da extramun- 
danidade do Espírito", o qual seria o equívoco cometido por Scheler, porém, não por Plessner. Por outro lado, este seria o tributo vitalista e neo-vitalista pago por Scheler à Ludwig Klages (2010), Hans Driesch (1914) e a toda doutrina do vitalismo em geral.

O esquema dos graus do orgânico proposto por Scheler seria, segundo Gehlen, uma "ordenação enganosa" na qual "não podemos confiar" (Gehlen, 1980, p. 24-25), tendo em vista que de tal ordenação derivam-se somente duas possibilidades: (1) tal como encontramos na teoria clássica da origem das espécies, para Scheler, a diferença entre a inteligência prática manifesta nos animais e aquela propriamente humana é apenas gradual, ou seja, haveria entre ambas um continuum no qual o homem distinguir-se-ia dos animais tão somente por um maior refinamento, enriquecimento e complexidade das "propriedades" animais já de antemão concebidas; (2) a diferença entre as inteligências práticas animal e humana estaria na disposição especial desta para a pura inteligência, isto é, estaria em sua abertura para o Espírito. O Espírito seria concebido de forma desnaturalizada como denegação das funções vitais que o precedem, ou seja, seria o extravivente. Portanto, Scheler distingue o homem do animal por um viés antinatural.

Nesta lógica, o esquema de Scheler concebe o homem como um microcosmo que não somente reúne em si, mas também supera, todos os atributos do animal. A hierarquia natural do mundo orgânico inicia-se nos seres instintivos inferiores (em geral, plantas), transita até os animais superiores dotados de memória e inteligência prática, e, por fim, encerra-se com o homem, o qual reúne em si todos os atributos animais antecedentes e os coroa com o Espírito. Esta ordem evolutiva de operações que se estendem cumulativamente do instinto ao Espírito é rechaçada por Gehlen a partir de duas refutações: (1) Gehlen não só recusa a definição de instinto proposta por Scheler, como enfatiza que o comportamento instintivo e o inteligente são mutuamente excludentes; (2) segundo Gehlen, não é possível compreender a capacidade de aprendizado do homem a partir de uma sistemática analogia zoológica 
tendo em vista que as operações humanas de assimilação e aprendizado são de natureza diversa.

A primeira refutação apropria-se da clássica definição do conceito de instinto proposta pela etologia de Konrad Lorenz em seu artigo "Sobre a formação do conceito de instinto" (Über die Bildung des Instinktbegriffs), de $1937^{2}$. Gehlen assinala que com Lorenz nasce uma nova psicologia animal contraposta a de Herbert Spencer e Lloyd Morgan. Ambos, juntamente com McDougall, concebem o instinto como o grau ontogenético e filogenético anteriores às operações superiores do Espírito. A partir das experiências etológicas de Lorenz, todavia, demonstrou-se que há "dois tipos fundamentalmente distintos de processos cinéticos inatos e mantenedores da espécie: as reações de orientação (as quais dependem de estímulos-guias externos) e os movimentos instintivos" (Gehlen, 1980, p. 26). As reações de orientação, as quais Lorenz denominou taxias, são "provavelmente as raízes filogenéticas de modos de comportamentos complicados e variáveis e que, embora apareçam ao mesmo tempo que os instintos autênticos, não são redutíveis a ele; quer dizer: distinguem-se totalmente deles" (ibidem, p. 27). As reações de orientação envolvem o uso dos sentidos e do instinto quando, por exemplo, um animal está à caça de sua presa. $\mathrm{O}$ ataque à presa envolve o uso de habilidades e mecanismos sensíveis, os quais calculam, diante de uma situação concreta e variável, a melhor estratégia para a consecução dos fins que instinto aciona.

Qual seria, então, a definição de instinto? Segundo Gehlen:

os instintos autênticos são movimentos, ou melhor, modelos ou figuras de movimentos de um tipo muito especial, que transcorrem em virtude de um automatismo inato e são dependentes de processos de produção de estímulos endógenos internos. [...] Os movimentos instintivos (quer

\footnotetext{
${ }^{2}$ Lorenz responde a várias das críticas feitas por Gehlen em um artigo de 1950 intitulado "O todo e a parte na sociedade animal e humana" (Ganzheit und teil in der Tierischen un Menschlichen gesellschaft). Ambos os artigos de Lorenz podem ser lidos em português no livro Três ensaios sobre o comportamento animal e humano.
} 
dizer: figuras ou modos de comportamentos inatos e típicos da espécie) são acionados ou postos a funcionar, normalmente, pelos objetos adequados, que o animal encontra no mundo que o rodeia. Quer dizer, seus companheiros de espécie ou parceiro sexual, a presa, o inimigo, etc. Ou melhor: não são acionados por estes objetos, mas por certos "sinais" sumamente específicos que há neles e que podemos chamar "acionadores". (Gehlen, 1980, p. 27)

O instinto é uma informação genética que se manifesta inequivocamente em certas situações nas quais os acionadores entram em cena. A etologia de Lorenz descobriu que tais acionadores do instinto podem ser simulados experimentalmente por meio de estímulos artificialmente produzidos de maneira que o comportamento instintivo se faça evidente para o investigador. A crítica de Gehlen a Lorenz, neste aspecto, repete o argumento de sua crítica à hierarquia dos graus do orgânico de Max Scheler: a aplicação imediata do conceito de instinto oriundo da observação empírica dos animais não serve como experiência análoga para uma definição do comportamento humano. Não obstante, Gehlen concorda com Lorenz quando este afirma que a qualidade essencial do homem consiste na redução do instinto, ou seja, consiste na "desmontagem" evolutiva e natural de quase todas as "coordenações firmemente montadas de 'acionadores"' (ibidem, p. 29).

Chegamos então ao cerne da primeira refutação de Gehlen acerca do esquema dos graus do orgânico de Scheler:

Não existe de nenhuma maneira uma relação de grau entre um comportamento instintivo e o inteligente, senão, como já viu Bergson ${ }^{3}$, uma

\footnotetext{
${ }^{3}$ Bergson assinala que: "O erro capital que, transmitido desde Aristóteles, viciou a maior parte das filosofias da natureza foi ver na vida vegetativa, na vida instintiva e na vida racional três graus sucessivos do desenvolvimento de uma única tendência, quando são três direções divergentes de uma atividade que se cindiu com o seu crescimento. A diferença entre elas não é uma diferença de intensidade, nem, mais genericamente, de grau - é uma diferença de natureza. [...] a inteligência e o instinto se opõem e se completam". Para Bergson, desde Aristóteles, somos tentados a conceber o instinto e a inteligência como "ativi-
} 
tendência a excluírem-se mutuamente. Mesmo nos casos bastante numerosos em que taxias, reflexos condicionados ou autoadestramentos estão conectados ao comportamento instintivo, podemos examiná-los analiticamente em separado. Os maravilhosos e "obstinados" movimentos instintivos descansam em processos internos de acumulação de energia de reação específica, comportam-se de acordo com os hormônios, produzem estímulos internos e impulsionam o organismo a atuar; este atua infalivelmente quando um "acionador" coordenado, agindo sobre os centros de percepção, desconecta os freios centrais. Estes processos são, desde o ponto de vista fisiológico, completamente distintos das reações de orientação (taxias), assim como os adestramentos, processos de aprendizagem e "inspeção", os quais tornam possível um comportamento variável segundo a mudança das circunstâncias [...]. (Gehlen, 1980, p. 29)

O comportamento instintivo é automático, autônomo e determinado de antemão pelos condicionadores. A inteligência prática é variável, sujeita à iniciativa do animal e condicionada pela circuns-

dades das quais a primeira seria superior à segunda, e a ela se sobreporia, quando não são realmente coisas da mesma ordem, que não se sucedam uma à outra, nem entre as quais se possam estabelecer diferenças de grau" (Bergson, 2009, p. 153; grifo do autor). O modelo bergsoniano concebe tais faculdades como atributos interpenetráveis, os quais se manifestam de maneira diversa em cada organismo vivo. Ademais, a inteligência humana não deve ser confundida com a noção de inteligência nos animais. O homem, entendido como homo faber manifesta sua inteligência no fabrico de objetos artificiais "especialmente utensílios fabricadores de utensílios" - os quais variam indefinidamente em forma e utilidade, bem como mostram-se imperfeitos porque construídos penosamente com qualquer matéria-prima, isto é, visam tirar o ser vivo de qualquer nova dificuldade, além de multiplicarem-se em novas necessidades. O homo faber torna-se mais livre com tais utensílios. Já a inteligência animal, mobilizada em conjunção com o instinto, produz utensílios que, embora requeiram a iniciativa do ser vivo, constituem-se num "órgão artificial que prolonga o organismo natural" (ibid., p. 159), ou seja, "o instrumento faz parte do corpo que o utiliza, e correspondente a este instrumento, há um instinto que sabe servir-se dele" (ibid., p. 157). Assim, a teia de aranha de uma viúva-negra seria um utensílio cujo fabrico é o resultado híbrido da inteligência a serviço do instinto, isto é, são utensílios perfeitos. Os utensílios humanos, pelo contrário, são produtos da pura inteligência e não possuem a determinação inata do instinto. 
tância. Numa palavra, para Gehlen, o instinto é a negação da inteligência, não a sua condição motriz.

A segunda refutação a Max Scheler incide sobre a aplicação análoga do esquema zoológico para a caracterização das faculdades humanas. Este "paralelismo" não é válido sequer para compararmos animais cognitivamente inferiores entre si. As gralhas e os corvos, por exemplo, embora possuam as mesmas coordenações instintivas, apresentam uma inteligência prática distinta. Ambos ocultam restos de comida, porém somente o corvo aprendeu que esta prática só tem êxito se ninguém o estiver observando. Por isso, adverte-nos Gehlen, "temos de movermo-nos fora da sistemática zoológica" tendo em vista que "os gêneros de operações humanas não concordam exatamente com as zoológicas" (Gehlen, 1980, p. 30). Como afirma Buytendijk (1928, p. 33), "[a] lei darwiniana de que nos vertebrados o aumento da capacidade de aprender corre paralelo ao desenvolvimento zoológico e alcança seu ponto máximo na capacidade humana de aprendizagem se dá em contradição com os fatos".

Gehlen cita vários exemplos que contradizem este paralelismo. Animais arborícolas, em geral, como os esquilos, os macacos e os papagaios, a despeito das evidentes diferenças entre eles, possuem atributos de inteligência prática e de orientação. Sabe-se que os esquilos encontram as nozes que esconderam apenas com a percepção óptica que retém na memória. Ao se aproximarem de sua comida diligentemente escondida, fazem rodeios para averiguar se há algum outro animal observando-os e, só então, recolhem-na. O gesto de fazer rodeios, desde as descobertas de Wolfgang Köhler (1925), é qualificado como um atributo de animais superiores, o que não se aplica aos esquilos. Há casos de insetos caçadores como as libélulas, as quais, em certas situações, giram a cabeça para mirar suas presas e persegui-las. Ao mirar uma presa, o animal faz um mapeamento da situação, e só a partir daí, age. Isto implica que tal animal objetiva a sua "consciência" em relação a um dado objeto, ainda que tal objetivação seja dada, em grande 
parte, pelos acionadores do instinto. Segundo as observações empíricas de Buytendijk (1928, p. 243), estas reações de orientação não são privilégio de animais superiores, mas de vários animais arborícolas e predadores. Por outro lado, as reações instintivas, tidas como típicas de animais inferiores, estão presentes também em animais do topo da hierarquia orgânica. O instinto, como sabemos, põe em ação cadeias de movimentos inatos mediante uma reação incondicionada do acionador. As ações instintivas sociais dos pássaros, como observa Buytendijk, operam em conjunção com a experiência e com a observação de objetos e reações concretas, como, por exemplo, quando uma pata-mãe, em defesa de seus filhotes recém-nascidos, inicialmente, atende indiscriminadamente ao pio de qualquer filhote que esteja em sua proximidade, porém, algumas semanas depois, atende apenas ao pio dos seus próprios filhotes, os quais passa a reconhecer "pessoalmente".

Estes exemplos nos servem para demonstrar que "a inteligência dos animais, considerada em si mesma, de nenhum modo, segue sua ordem de distribuição dentro da sistemática zoológica" (Gehlen, 1980, p. 30). Numa palavra, Gehlen quer demonstrar que o esquema evolucionista de Darwin é arbitrário, não suporta a mais perfunctória prova empírica e, portanto, não possui estatuto científico. A sistemática zoológica da natureza não obedece a esta esquematização rígida, e o lugar que o homem nela ocupa não deve ser nem antinatural - como advogava Max Scheler ao eleger o "Espírito" como atributo deificado do homem - tampouco hipernatural - conforme o esquema evolucionista que distingue o homem dos demais animais por uma questão de grau e trata o espírito como um epifenômeno das condições orgânicas. A antropologia de Gehlen, pelo contrário, deve ater-se a "uma lei estrutural especial que é igual em todas as propriedades humanas" e que deve ser entendida desde a perspectiva segundo a qual o homem, enquanto projeto da natureza, é um ser práxico, isto é, 
seu corpo e seu espírito se constituem num circuito uno voltado para a ação.

Se a linha progressiva dos estratos do orgânico não nos serve como parâmetro de distinção da inteligência dos animais entre si, não nos serve, por conseguinte, como parâmetro para distinguirmos a inteligência do homem em relação às capacidades de assimilação cognitiva do animal. Esta diferença só poderá se tornar evidente se provermos as leis estruturais das operações animais e seus limites operacionais em relação às leis operacionais humanas. Gehlen propõe-nos assim três leis estruturais das operações animais:

(1) A lei do reflexo condicionado como atributo par excellence do aprendizado animal. Segundo esta lei, os animais, em geral, assimilam as experiências que têm tido resultado favorável conforme a importância vital que estas adquirem na sua repetição cotidiana. Estas experiências, embora sejam estímulos exteriores ao instinto do animal e, portanto, não tenham qualquer significado biológico para ele, podem, pela repetição, assumir um "significado" vital. É óbvia a alusão de Gehlen ao cão de Pavlov na proposição desta lei: "Quando de um estímulo exterior, carente de significado biológico para o animal segue-se outro que está pleno de significado e que aciona uma reação instintiva inata, o animal vai se comportando pouco à pouco em relação ao primeiro estímulo como se fosse para ele o anúncio de um acontecimento biológico importante" (Gehlen, 1980, p. 32). O estímulo exterior atua, portanto, como um "sinal" que se comunica com as forças instintivas e desencadeia uma reação vital;

(2) a lei da consummatory action instintiva como mecanismo de aprendizagem dos animais vis-à-vis a des-vinculatividade do aprendizado humano. De acordo com esta lei, os animais só aprendem a operar inteligentemente a partir de situações con- 
cretas, atuais e presentes nas quais a operação esteja plena de significado para o instinto. A operação de aprendizagem adquire seu sentido teleológico no instinto do animal como uma ação de consumação do mesmo. O comportamento instintivo do apetite (fome), por exemplo, exige que o animal assimile inteligentemente diversas operações, porém, todas estas variações comportamentais ocorrem em função de uma única ação de consumação instintiva: a satisfação do apetite. É este instinto, como força-motriz constante, que determina o telos das operações de aprendizagem do animal, de maneira que este possa ser adestrado ou se autoadestrar para uma reação não-inata, apreendida. É precisamente a partir do uso deste mecanismo instintivo que podemos adestrar animais domésticos e selvagens. O mesmo vale, por exemplo, para os cães criados nas ruas, os quais aprendem a atravessar avenidas e observar o fluxo de automóveis para sobreviverem. O aprendizado humano, contrariamente, se dá pelo desvínculo entre as operações de assimilação e os mecanismos pulsionais das forças instintivas. $\mathrm{O}$ exercício de aprendizagem humana não exige uma situação biologicamente extraordinária, ele pode se dar pela simulação ou pelo artifício, e, mais do que isso, ele se dá pela dissociabilidade do comportamento em relação ao contexto de cada situação concreta. É nesse sentido que Gehlen vê neste atributo "a essência do homem como ser simbólico, uma vez que pertence à essência do símbolo o fazer referência a algo não dado e que não se pode deduzir do contexto" (Gehlen, 1980, p. 33). Em outras palavras, este seria o atributo da des-vinculatividade, o qual permite que a execução de uma atividade experimental qualquer possa suspender a um só tempo "a pressão das indigências biológicas de grande urgência, como também as traços típicos das situações-prêmio", nas quais o instinto direciona o comportamento. Contrariamente, a aprendizagem humana opera de maneira independente e liberada no que diz respeito aos estímulos próprios às situações cambiantes. 
Os animais aprendem em situações concretas, definidas e direcionadas ao instinto, o qual, em geral, é acionado por algum "sinal" cuja repetição se demonstrou útil e vital para a sobrevivência. O homem aprende pela liberação dos órgãos dos sentidos porque possui uma infraestrutura morfológica e fisiológica que se organiza a partir de uma redução dos instintos. Esta forma de aprendizagem "livre do instinto" não é resultado do uso da inteligência, mas está arraigada numa "estrutura muito profunda do humano". Daí que seja "especificamente humana a possibilidade de descarga, liberação ou isenção do comportamento" (ibidem, p. 33);

(3) a lei da curiosidade como atributo da aprendizagem animal vis-à-vis a faculdade da investigação autêntica como atributo exclusivamente humano. A paixão de Konrad Lorenz pelos animais, especialmente os corvos, levou-o a distinguir uma categoria de "animais curiosos", os quais, segundo seus estudos, buscam ativamente situações de aprendizagem e, por isso, perseveram com a investigação por amor a ela mesma. O corvo, neste aspecto, teria atributos cognitivos mais próximos aos atributos humanos do que, por exemplo, os chimpanzés. Segundo Lorenz, estes animais curiosos prestam atenção aos estímulos externos desconhecidos para mediante uma investigação "sistemática" de todos os estímulos elegerem os que têm importância biológica (Lorenz, 1975c). Gehlen avalia estas afirmações de Lorenz como uma "tese desmesurada", que não consegue distinguir entre a curiosidade dos animais e a capacidade de autêntica investigação própria do homem.

Postas estas objeções, presumo que seja a hora de nos concentrarmos nas leis estruturais da constituição humana. Este será o programa de pesquisa proposto por Gehlen de agora em diante. 


\section{Handlung Zuzammen: as leis estruturais da constituição humana e seus modos de operação}

Ao definir as Leis Estruturais da Constituição Humana (LECH), Gehlen tem por propósito captar a especial posição psíquica e morfológica do homem. Para ele, as operações humanas se distinguem da constituição humana propriamente dita, uma vez que esta precede e determina a natureza e a projeção daquelas, sobretudo no que diz respeito ao desdobramento teleológico que as operações humanas terão quando, em sua execução, exercerem a função de ações de descarga (Entlastungsgefahren). Como veremos, o êxito das operações humanas depende da formação de um ponto gravitacional em torno do qual o homem possa domesticar e orientar o desassossego constitutivo de seus sentidos, de suas pulsões e de suas impressões a fim de atingir o fim vital máximo de todo organismo: a sobrevivência. Quais seriam, a rigor, estas Operações Humanas (OPHU)? Seriam: a linguagem, a consciência, a fantasia, a cinética do movimento corporal (Kinefantasia), a dinâmica da percepção sensório-motora e a inteligência prática e simbólica. As operações humanas são, portanto, desdobramentos das leis estruturais da constituição psicossomática do homem e, concebidas per se, não conferem peculiaridade ao humano vis-à-vis os demais animais. Gehlen quer, assim, refutar as teses que fundam a singularidade humana em tais operações, identificando o homem como "ser da linguagem", "animal racional", "ser da consciência", "ser da ideação" etc.

As LECH's são os fundamentos protoestruturais a partir dos quais se organizarão as modalidades de percepção humana do mundo e do meio ambiente. Como assinala Gehlen, as LECH's compõem a base pré-loquial (Gehlen, 1980, p. 53) - isto é, anterior à linguagem - da ação humana. Como sabemos, elas são da ordem de seis (ver diagrama I, mais adiante). As OPHU's podem ser enumeradas em linguagem, fantasia (fantasmas cinéticos, fantasmas de poder), consciência (ideação e elevação simbólica) e inteligência. Devemos ter em mente que estas operações em si não 
são atributos exclusivamente humanos, porém, o processo pelo qual elas são levadas a cabo, desde a protoconstituição humana até fabricação do mundo, sim, são de natureza eminentemente humana. Quer dizer, a condição relacional entre as leis estruturais da constituição humana e a mobilização dos sentidos (orientação da percepção, das impressões e autodomesticação) no exercício das operações humanas é que confere singularidade ao homem na ordem do mundo natural. Por processo aqui, portanto, Gehlen designa a relação de continuidade entre a base protoestrutural das LECH's e seus desdobramentos na ação humana, isto é, nas OPHU's. Este processo relacional entre LECH e OPHU é o que denominamos comportamento. Gehlen quer desvendar como se constroem ou se estruturam as operações humanas, por isso, tem que começar a explicá-las a partir das bases constitutivas psicossomáticas do homem. O comportamento é, portanto, a forma expressiva vital a partir da qual as operações humanas desencadeiam as ações de descarga que "superam" ou "sublimam" as limitações morfológicas e orgânicas da constituição humana.

Para entendermos a singularidade humana, precisamos compreender as estruturas constitutivas do homem e como tais estruturas produzem estas operações a que nos referimos. O que dá origem à linguagem humana? Como esta surgiu? A que demandas estruturais da constituição psicossomática a linguagem atende? As operações humanas estão cartesianamente isoladas ou elas atuam em conjunto? Como a linguagem está referida à consciência? E esta, como se conecta à fantasia?

As leis estruturais da constituição humana formam um sistema inconsútil no qual as deficiências e as proficiências morfológicas, pulsionais e perceptivas do homem estão integradas em circuito e são responsáveis por uma multiplicidade de funções, tais como a percepção visual em conexão à percepção táctil, a linguagem, o pensamento, os fantasmas cinéticos do movimento corporal, as propriedades simbólicas do trato com os objetos do mundo humano (forma, peso, textura, cores), o uso das mãos livres em virtude 
da posição ereta etc. A constituição psicossomática do homem determina as formas de percepção sensorial de si e do mundo à sua volta (meio ambiente ou "circum-mundo"). A partir destas formas de percepção, o homem age, isto é, põe em movimento um conjunto de operações que se resolvem nas ações de descarga: a fabricação do mundo humano por sua própria indústria e segundo as condições que vitalmente a ele convém. Este é, portanto, um sistema de integração das forças humanas vitais básicas: a constituição corporal, as percepções sensório-motoras, o controle destas percepções, as operações humanas e, por fim, as ações de descarga.

Para definirmos o que é a descarga, precisamos de antemão enumerar tais leis estruturais da constituição humana (LECH) e explicá-las. Gehlen não as enumera, certamente, porque não as quer estanques ou tratadas de forma isolada, tendo em vista que se trata de um circuito. Contudo, para fins didáticos, podemos assim divisá-las:

(1) O homem é um ser cuja constituição morfológica não é especializada, isto é, não é adaptada a qualquer condição natural ou a qualquer meio ambiente. Em decorrência de seu primitivismo orgânico, resultado do retardamento de seu desenvolvimento somático, o homem é um ser prejudicado pela carência de adaptação animal. Este caractere já fora estudado antes por Louis Bolk (1927) e fora denominado de neotenia, isto é, a pedomorfose natural constitutiva da anatomia humana. A comparação ontogenética do desenvolvimento morfológico do homem vis-à-vis os chimpanzés, por exemplo, evidencia que nascemos prematuramente, incapazes de nos provermos autonomamente durante o longuíssimo período de infância. Enquanto os demais animais bem cedo se lançam à natureza e encontram nela os subsídios para sua sobrevivência, adaptandose ao meio ambiente que lhes é próprio, o homem é um ser nãonatural, não-adaptado, e, portanto, não possui meio ambiente 
propriamente dito, possui mundo, no sentido dado ao termo por Uexküll (1921). Comparado à Gestalt especializada dos animais que se ambientam, em determinada região segundo as condições climático-ambientais desta, o homem é uma negação dos princípios regulares da physis animal.

Gehlen faz uso da comparação zoológica entre o homem e os animais para reafirmar sua primeira $\mathrm{LECH}$, a não-especialização morfológica do homem enquanto insígnia negativa. Esta zoologia comparativa só é útil para o autor quando ele pretende evidenciar a posição morfológica especial do homem na natureza, porém, não se presta a postular uma ordem progressiva das faculdades animais de forma que o ser humano seja o pináculo de uma grande cadeia do ser. Assim, Gehlen acentua as deficiências deste homo inermis, isto é, deste animal inerme, que, embora fragilmente exposto às adversidades da natureza, desprovido de mecanismos naturais de defesa, ainda assim, sobrevive e se prolifera. A evolução dos demais animais implica na especialização dos órgãos, e a evolução do homem decorre da anulação progressiva destes. É evidente aí a utilização da teoria da anulação dos órgãos de Paul Alsberg (1922), a quem Gehlen não cita. A história natural da evolução do homem é, neste aspecto, a história da involução dos seus órgãos. Desta incapacidade de adaptação à natureza se desdobra a segunda LECH, qual seja:

(2) O homem é um animal carente de instintos, uma vez que sua evolução filogenética o conduziu a uma redução progressiva dos operadores instintivos, os quais encontramos em toda e qualquer espécie do mundo animal. Se considerar sua condição natural, o homem é uma espécie facilmente exposta à extinção. Como o homem supera sua indigência de instintos e assegura sua sobrevivência? Ele supera porque é capaz de dissociar, isto é, criar um hiato entre suas pulsões vitais e suas ações. As operações humanas são executadas a partir da suspensão volun- 
tária das pulsões, o que permite ao homem dominar e autodeterminar sua consciência para um fim vital prático. Este hiato entre ações e pulsões possibilita-nos uma leitura objetiva e ascética da realidade e suas mutações. A isto, Gehlen denomina experiência, quer dizer, a adequação das operações humanas às infinitas possibilidades de objetivação do mundo e suas circunstâncias. No homem, as indigências elementares não podem dispor dos acionadores de instinto. Daí a necessidade de "orientá-las mediante a experiência" e por meio das imagens que esta engendra no fluxo das operações vitais. A experiência produz "fantasmas de êxito" e com eles a "ampliação do círculo de atividade humana no mundo", o qual é "permanentemente ampliado e 'forçado' pelo conhecimento e pela ação". Daí o sentido da frenabilidade das pulsões, quer dizer: "por entre parêntesis", postergar, impedir que a força das pulsões tenha livre trânsito na execução de uma ação. A faculdade de "reter" as pulsões, de variar o comportamento judicioso, "põe a descoberto um 'dentro', um interior". Este interior e seu hiato "é a base vital do fenômeno chamado alma" (Gehlen, 1980, p. 62). ${ }^{4}$

Ao referirmo-nos às pulsões humanas, imediatamente aludimos à estrutura dos instintos humanos e à distinção desta em relação à estrutura instintiva dos animais em geral. Conforme dito anteriormente, o homem possui uma estrutura instintiva reduzida e indigente. Para esclarecer a natureza desta indigência de instintos e a forma como o homem supera vitalmente tal deficiência, Gehlen faz uso da imagem do cão de Pavlov. Segundo aquela imagem, o animal vive num círculo de sugestões sensoriais imediatas, no qual suas reações são instantâneas e determinadas pelos acionadores do instinto. A inteligência animal seria de natureza "protofenomenal",

\footnotetext{
${ }^{4}$ Assim, Gehlen define a alma: "Na linguagem comum chamamos 'alma' em primeiro lugar a capa ou estrato das pulsões que se dão a conhecer em imagens e representações, nas indigências conscientes e nos interesses orientados" (Gehlen, 1980, p. 62).
} 
isto é, conduzida de antemão pelas pulsões imediatas do instinto no aqui-agora da situação. Não há a "intencionalidade da consciência" em direção a um "tender-para", assim como não há uma projeção futura para experiência adquirida. Em Pavlov, a formação do "reflexo condicionado" pressupõe uma reestruturação de toda situação na percepção, de tal modo que o sinal inicial, prenhe de significado, se confirma no comportamento subsequente em situações análogas. Quer dizer, o animal vive o agora, segundo a lei inexorável do instinto e segundo o ritmo que a natureza determina. Esta unidade harmônica entre os animais e o ritmo da natureza é o que Gehlen denomina Biocenose (de bios e koiné, isto é, "a vida em comum de animais e plantas"). Os animais vivem com o tempo; o homem conhece o tempo. Por isso, os instintos básicos, tais como a fome ou a pulsão sexual, manifestam-se nos animais como um alerta de busca no qual um dos sentidos especializados - o olfato ou a visão, por exemplo - é acionado em direção a uma "presa". O instinto move o animal com um autômato. O homem, pelo contrário, cria em seu entorno, por sua própria indústria, o "espaço vazio" de um mundo abarcável com o olhar ("supervisível"), rico em insinuações e à disposição como ser-aí. Ele não vive o agora, suspende-o para conhecer melhor as condições objetivas e, assim, agir. A pressão do instinto atua sobre ele, mas é igualmente suspensa pela inteligência autônoma. Nesta lógica, o homem deve ser investigado como único ser vivo capaz de reduzir ao mínimo, sensorial e motoricamente, os pontos de contato com a situação do "agora" (ibidem, p. 54).

(3) O homem é o único ser dotado do atributo da abertura ao mundo (Weltoffenheit), isto é, abertura ilimitada aos estímulos e às impressões oriundas de seu complexo aparato perceptivo e cognitivo. As percepções humanas não têm qualquer conexão com os instintos reduzidíssimos que possui. Estar aberto ao mundo, portanto, pode significar, tautologicamente, uma carência de adaptação animal que obriga o homem a mobilizar e 
organizar suas infinitas possibilidades de percepção para um fim que ele se auto-impõe, acima e além das pulsões instintivas. Por outro lado, esta abertura ao mundo pode ser entendida como não-pertencimento a qualquer ambiente-fragmento da biosfera, o que permite ao homem construir seu próprio ambiente. Eis aí a explicação do porquê o homem ser o único ser vivo que pode sobreviver em todas as partes da terra. Ele é, pois, "um ser carente desde o ponto de vista orgânico, por isso mesmo, aberto ao mundo, quer dizer, incapaz por natureza de viver em um ambiente fragmentário concreto" (ibidem, p. 38).

(4) O homem é um ser que padece de uma sobrecarga de percepções que não se realizam no telos do instinto, quer dizer, ele sofre de uma "superabundância de estímulos não-animais, impressões sem finalidade". As percepções dos animais adquirem "sentido" e "significado" (se é que podemos usar estes termos no caso de um estudo zoológico) na pulsão advinda do instinto e nas imposições do meio ambiente natural. As impressões humanas, como não possuem um sentido teleológico vital, consumar-se-ão na finalidade que o homem estabelece para si, isto é, consumar-se-ão na tarefa que o homem se auto-atribui. Quer dizer, o ser humano domestica e canaliza suas impressões no intuito de consumá-las. Neste caso, não há meio ambiente, há um mundo imprevisível e aberto no qual a subsistência da vida depende da capacidade falível do homem em descarregarse com êxito. Ao olhar e tocar um objeto qualquer, por exemplo, um pedaço de madeira ou uma pedra, o homem é invadido por uma pletora de impressões vazias de significado e de finalidade (cor, forma, peso, textura). A princípio, não há uma orientação dada pela consciência que possibilite saber o que é aquele objeto e para que ele pode servir. Estas orientações advirão do manuseio e da experiência humana em diversas situações, as quais este agente não pode prever. Ele está aberto ao mundo, e o mundo é um campo imenso de impressões desprovidas de 
significado e prenhe de demandas. Um pedaço de madeira pode servir para alimentar uma fogueira, para construir uma cabana ou uma embarcação ou para o uso violento em situações que requeiram a autoproteção. O mesmo vale para uma pedra ou para qualquer outro objeto. Como afirma Gehlen, "a disponibilidade" potencial destes objetos está "oculta" e só será descoberta e preenchida de significado quando o agente orientar-se, mediante o intercâmbio e a experiência, para um centro concreto de ação. O homem é, nesta lógica, um ser obrigado a ser industrioso, a orientar-se em meio à pletora de insinuações ópticas e tácteis: "orientar-se quer dizer reduzir a inundação de impressões a centros concretos; dominar ao mesmo tempo estes centros e descarregar-se da pressão advinda da pletora imediata de impressões" (Gehlen, 1980, p. 46). Desde a infância, o homem é um ser desassossegado por esta tarefa: construir um significado concreto e útil à vida para todas as impressões que lhe chegam.

Por isso, o mundo circundante do homem é "elaborado", quer dizer, os utensílios que o povoam devem ter disponibilidade, direção e devem ser produzidos pela mão humana. As mãos operam em colaboração com todos os sentidos, sobretudo, os olhos, que, em decorrência da posição ereta, "supervisionam" o mundo, atribuindo a cada coisa seu respectivo valor de uso e de trato. Cada objeto é construído, experimentado e valorado penosamente. A indústria humana, portanto, é difícil, penosa e lenta. Cada instrumento ou constructo humano requer, para o êxito da sua finalidade, um tipo de aprendizado no qual as pulsões devem ser suspensas, ou seja, o homem deve "retirar-se de tais situações imediatas por sua própria indústria; estabelecer uma distância". Gehlen sintetiza esta LECH no seguinte excerto:

A abertura ao mundo, vista desde aí, é fundamentalmente uma carga. O homem está submetido a uma superabundância de estímulos de tipo não-animal; a uma pletora de impressões "sem finalidade" que afluem a 
ele e que ele tem que dominar de alguma maneira. Frente a ele não há um meio ambiente (circum-mundo) com distribuição de significados realizados por via instintiva, senão um mundo (melhor seria expressá-lo negativamente: um campo de surpresas de estrutura imprevisível) que só pode ser elaborado, quer dizer, experimentado, mediante "pré-visão" e "pro-vidência". Já que há uma tarefa de urgência física e importância vital, a saber: por seus próprios meios e por si mesmo, o homem há de descarregar-se, quer dizer, transformar por si mesmo os condicionamentos carenciais de sua existência em oportunidades de prolongamento da vida. (Gehlen, 1980, p. 40-41)

Esta operação de autodescarregar-se é, ela mesma, o chamado princípio de descarga. Este princípio é "a chave para compreensão da lei estrutural presente nas construções de todas as operações humanas" (Gehlen, 1980, p. 41). Todas as "carências" da constituição humana - a não-adaptação ao meio ambiente natural, a nãoespecialização dos órgãos, a deficiência de instintos - são transformadas pelo homem, por si mesmo e através de sua ação, em meios de sua existência. Como esta transformação ocorre? Gehlen referese a dois tipos ação: as ações produtivas de superação da carga provocada pelas carências (descarga) e as ações de seleção das impressões e das ações que servem à vida. As primeiras são responsáveis pela construção do mundo humano não-natural, ou seja, a transformação do mundo natural em mundo humano; as últimas são operações de autoadestramento que permitem ao homem viver acima e além dos instintos e "mediante a sua própria indústria". Ademais, a mobilização dos sentidos, que podemos observar na execução das operações humanas, é empreendida de maneira intercomunicativa. Em sua vivência cotidiana, os sentidos não estão isolados cartesianamente; eles se comunicam entre si e com o movimento corporal na forma de uma integração sensório-motora. Este atributo é humano e se distingue dos demais animais porque não está preso às determinações do instinto. Percebemos que, neste duplo movimento de ação/descarga, o homem (a) se autodomestica para ter o controle ascético de seus instintos e (b) trans- 
forma o mundo natural para os fins que ele elege. Daí surge outra lei estrutural, o superávit pulsional humano.

(5) A estrutura pulsional humana tem como característica inata o "superávit pulsivo" (Triebüberschuss), que se manifesta como um excedente de energias vitais, as quais mobilizam o homem no curso de suas operações. Por pulsão, Gehlen define, portanto, as energias vitais inatas que incitam o homem à ação. Tais energias advêm da constituição orgânica, fisiológica e hormonal e assumem, no exercício das operações, um papel ambíguo entre a periculosidade da autodestruição (a qual somos suscetíveis) e a excelência industriosa da cultura humana. São respostas vitais à indigência estrutural humana. Como os instintos humanos são falhos e perturbáveis pela multiplicidade de impressões, além da infinidade de possíveis intercâmbios com o mundo aberto, o homem é obrigado controlar e frear tais pulsões. Para ele, os comandos pulsionais devem estar sempre subjugados pelo cálculo das possibilidades de ação inteligente numa dada circunstância. Por isso, Gehlen refere-se a duas particularidades da vida pulsional humana: (a) a frenabilidade ou contenção das pulsões mediante a autonegação de seu livre fluxo na ação e a (b) transferibilidade (ou plasticidade), isto é, a capacidade de translado das experiências análogas entre si para a superação das indigências e para a satisfação dos interesses. Ambas as particularidades só são possíveis porque o homem tem consciência da necessidade de autocontrole na busca pela satisfação das pulsões. Desde o primeiro processo de socialização, ainda criança, o homem se vê obrigado a aprender a controlar suas pulsões destrutivas e sem direção, filtrando-as

\footnotetext{
${ }^{5}$ Esta é a denominação dada por Alfred Seydel, o primeiro a identificar este caractere em sua crítica sociológica da consciência. O livro Bewusstsein als Verhängnis, de 1927, é uma obra póstuma, já que Seydel suicidou-se em 1924. $\mathrm{O}$ autor fora o primeiro a tratar do caráter perturbador da consciência, conforme descreve aqui Gehlen.
} 
para reter apenas o duradouro interesse pelas propriedades ocultas nas coisas que vê, tacteia e experimenta.

(6) O córtex hipertrofiado do homem, segundo Adolf Portmann, decorre do fato de que a ontogênese humana assume uma posição especial diante do subfilo dos vertebrados. Quando nasce, o homem tem um peso cerebral de aproximadamente três vezes o dos antropoides recém-nascidos e um peso corporal proporcionalmente superior (3200 gramas frente a 1500 do orangotango). A postura corporal ereta e os princípios de comunicação típicos da espécie são logrados aproximadamente um ano após o nascimento (Portmann, 1956, p. 68-80). A posição especial da ontogênese humana e suas particularidades morfológicas são evidentes em diversos aspectos: elevado peso corporal no nascimento, elevado peso cerebral, abertura dos sentidos, caráter incompleto do aparato cinético somado a um desenvolvimento tardio das proporções do corpo, das feições e da maturidade.

Por isso, o recém-nascido vem ao mundo numa espécie de parto prematuro "fisiológico", quer dizer, normalizado; ou bem, um "nidífugo secundário", o único caso dessa categoria entre os "vertebrados". O primeiro ano de vida humano após o nascimento tem um "caráter fetal" cuja característica é o "forte crescimento em tamanho e volume". Portmann denominou este período de "ano prematuro extrauterino" no qual combinam-se processos de maturação tais como assimilação da posição ereta, aprendizado da linguagem e dos meios de comunicação. Para Portmann, o homem é um "nidífugo desvalido". (Gehlen, 1980, p. 51)

A duração da gravidez de uma fêmea humana, uma vez comparada à duração média da gestação das fêmeas dos demais mamíferos, é acentuadamente curta, de modo que, se as fêmeas humanas coadunassem-se ao tempo médio de gravidez dos mamíferos, a gestação das mulheres perduraria vinte e um meses (Portmann, 1956). As fêmeas humanas parem aos nove meses porque o desenvolvimento cortical do primeiro ano da vida é, segundo Portmann, extrauterino; tal desenvolvimento não pode prescindir da vida 
social, a qual propiciará, mediante o aprendizado da linguagem, do bipedalismo e do uso das mãos, um crescimento exponencial do neocórtex. Caso este desenvolvimento ocorresse no útero materno, fatalmente, as fêmeas humanas não resistiriam ao parto. Ademais, o período curto de gestação permite que haja mais gestações, o que aumenta as taxas de natalidade e facilita a procriação. É por estas razões que as peculiaridades ontogenéticas e morfológicas do homem, segundo Gehlen, só podem ser entendidas em conexão com o modo de se formar nosso comportamento social (Gehlen, 1980, p. 51-52). A formação fetal e morfológica do homem, em sua completude, dá-se durante o processo embriológico uterino e, posteriormente, durante a formação comunicativa extrauterina. Ademais, a infância é extraordinariamente prolongada por uma década de dependência biológica em relação aos progenitores. Tão prolongado período de dependência só pode ser provido por instituições sólidas: a família, a infância, a maternidade e a moralidade.

Como estas operações humanas estão interligadas às ações de descarga? Quais são os mecanismos desta conexão? Como eles operam? Estas são as questões cabais que permitem entender que, através da lei de descarga, as operações anímicas se conectam às operações "inferiores", ou seja, o corpo se integra ao espírito, o uso das mãos à fala, os movimentos do corpo à consciência. Todas as operações humanas são desdobramentos de uma única função, a descarga, ou seja, a superação sobreficiente da indigência orgânica do homem. O diagrama a seguir sintetiza bem esta dinâmica da constituição vital humana: 
A biofilosofia dos graus do orgânico

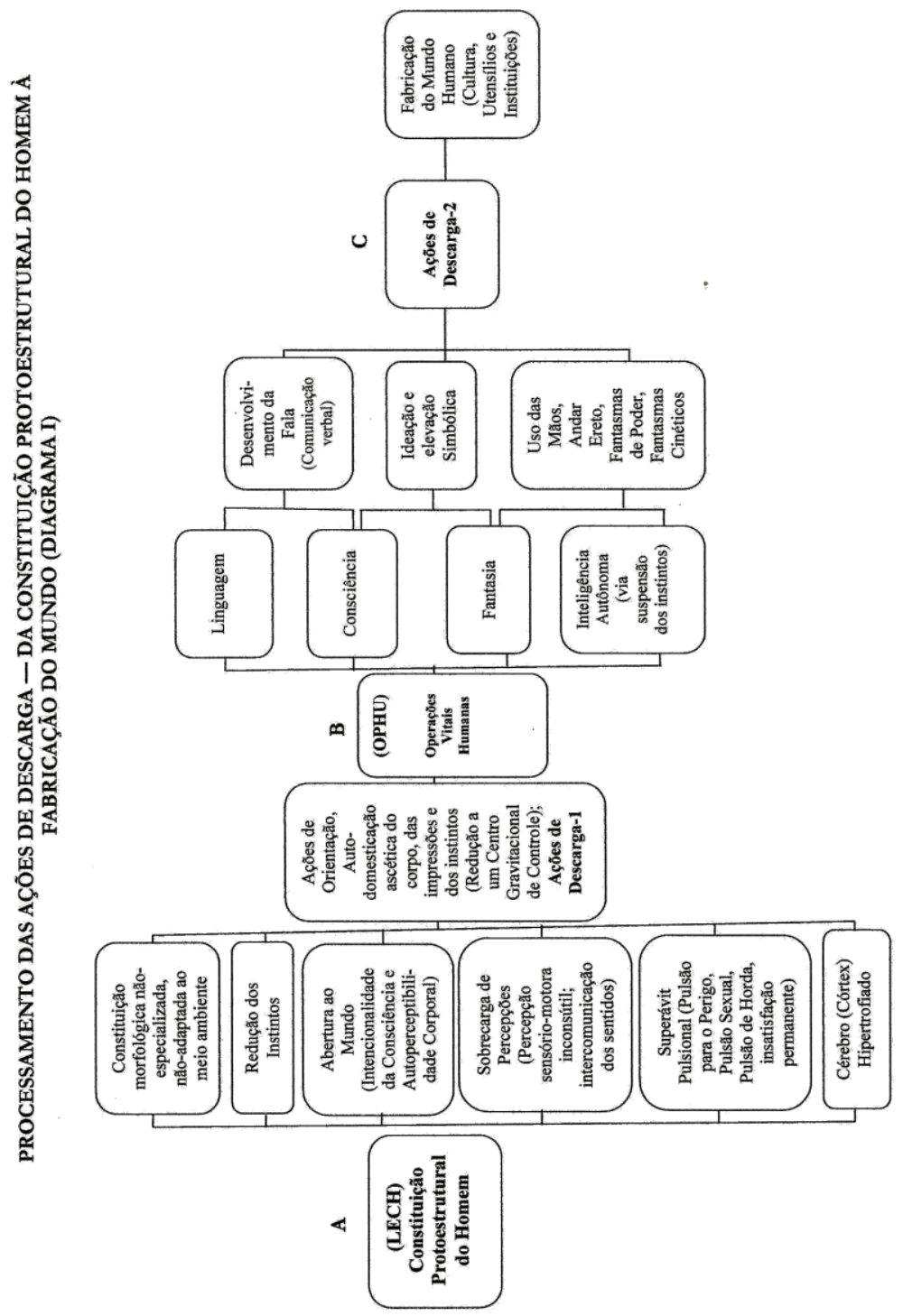

Princípios:Revista de Filosofia, Natal, v. 23, n. 40, jan.-abr. 2016.ISSN1983-2109 
Percebam que as Leis Estruturais da Constituição Humana subdividem-se em seis e estão interligadas como linhas que exercem a função de indutores. Tais indutores estão interconectados entre si. As estruturas constitutivas convergem para o centro do diagrama com as ações de orientação, autodomesticação e controle das impressões. As ações de orientação dirigem-se ao domínio práxico da pletora de impressões para que estas atinjam um fim útil à vida. Assim, se produzirá uma primeira ação de descarga, cujo intuito é iniciar o exercício das operações humanas vitais: linguagem, consciência, fantasia e inteligência. São estas operações que produzem os atributos da comunicação verbal, da ideação simbólica e do uso das mãos. Tanto as projeções do espírito quanto os utensílios próprios à subsistência humana decorrem desta segunda ação de descarga. E é com ela que o homem se lança à fabricação do mundo.

A primeira experiência de uma ação de descarga se dá pela autodomesticação dos instintos e dos sentidos. Sucede-se a ela uma segunda, levada a cabo pelas operações humanas que se orientam para a fabricação do mundo. Aí se dá a correlação entre a constituição morfológica do homem e a necessidade de orientação (descarga-1), assim como a correlação entre as ações de descarga e as operações humanas (descarga-2). A linguagem é a operação central para a execução das demais $\mathrm{OPHU}^{6}$. Temos aí um circuito no qual as LECH's se conectam às OPHU's mediante as operações de descarga.

\section{A consciência, a lei da descarga e a ontologia de Nicolai Hartmann}

O conceito de ações de descarga é, para Gehlen, a categoria essencial de sua antropobiologia empírica. Como tal, este conceito pode ser definido por uma única lei, a lei das ações de descarga,

\footnotetext{
${ }^{6} \mathrm{Na}$ hierarquia das operações humanas, a linguagem é a mais importante, porque articula todas as demais operações em sua natureza loquial e "para fora".
} 
que apesar de una, desdobra-se no exercício de todas as operações humanas, das mais fisiologicamente rebaixadas às mais espiritualmente elevadas.

Podemos agora definir preliminarmente o que vêm a ser estas ações de descarga (Entlastungsgefahren). Segundo a antropobiologia de Gehlen, descarga é toda operação ou ação humana que visa superar as deficiências morfológicas, instintivas e somáticas do homem. Como tal, a descarga realiza-se (a) como fabricação do mundo humano a partir da transformação do mundo natural (meio ambiente) conforme as finalidades dadas pela vontade e pela necessidade humana e, (b) como autodomesticação ascética das ações do homem em relação ao seu superávit pulsional e aos seus instintos diminutos, ou seja, como uma seleção teleológica vital dos meios materiais e anímicos úteis à vida. A descarga é, portanto, uma modalidade de ação e interação com o mundo natural singular ao homem, uma vez que só ele está obrigado a assim proceder. Ela envolve uma forma de realização proativa (a) e outra reativa (b), ou seja, uma forma (a) positiva e outra (b) negativa

Conforme deixa explícito o próprio Gehlen, a ideia de descarga deve ser entendida não apenas como mediadora do circuito LECHOPHU, mas como um conceito-pivô na estrutura categorial proposta por Nicolai Hartmann.

A doutrina ontológica das categorias de N. Hartmann tem mostrado que na estrutura por estratos do mundo, as categorias dos estratos ou camadas inferiores, como as inorgânicas, são mais fortes. Quer dizer, são indiferentes frente a existência das superiores e balizam o espaço dentro do qual se desenvolvem as superiores. E, inversamente, as categorias superiores são as mais dependentes. A vida anímica está pressupondo a orgânica e esta a inorgânica. Porém, são as mais ricas: cada camada ou estrato superior contém um "novum categorial"; quer dizer, novas estruturas e protofenômenos, que não se podem fazer derivar das camadas inferiores. Certamente, as categorias inferiores são as mais "débeis", quer dizer, estão dependendo da existência das inferiores, mas, frente a elas, são livres e autônomas. (Gehlen, 1980, p. 76) 
Para Hartmann, o homem é o único ser que agrega em si as quatro camadas do ser $\left(1954\right.$, p. 134) ${ }^{7}$, quais sejam (da superior à inferior): o espírito, o psíquico, o orgânico e o inorgânico. Ele resume sua estrutura categorial das camadas do ser no seguinte diagrama ${ }^{8}$ :

\section{AS QUATRO CAMADAS DO SER SEGUNDO NICOLAI HARTMANN (DIAGRAMA II)}

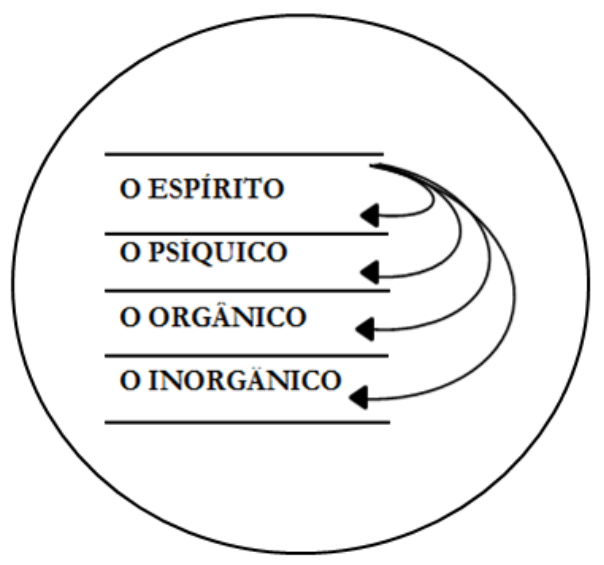

Hartmann acentua o caráter independente das camadas inferiores em relação às superiores. Para que haja espírito, é necessário antes que haja vida, e a vida é uma possibilidade remotíssima das combinações possíveis do mundo inorgânico. Este seria o limite de todas as teorias da vida. Como afirma Arnold Gehlen, "nenhuma

\footnotetext{
${ }^{7}$ Segundo Hartmann (1954, p. 134): "O homem contém em si todos os estratos ontológicos, e seria uma abstração vazia considerá-lo unilateralmente como se se tratasse somente de um ser espiritual".

8 Diagrama reproduzido com base no livro Introducción a La Filosofia. (Hartmann, 1969, p. 207).
} 
teoria explica como do inorgânico sai o orgânico, e, deste, o anímico e espiritual" (Gehlen, 1980, p. 77). Nesta ordem categorial do ser, a posição que o homem ocupa é análoga à possibilidade da vida surgir de combinações inorgânicas: uma "improbabilidade orgânico-biológica”. Hartmann, assim como Gehlen, distingue o psíquico do espiritual através do mesmo fenômeno, o hiato. Nas manifestações espirituais, "a consciência se separa de sua subordinação ao vital e se torna espiritual", entrando em "oposição com a consciência primária que está determinada pela vida impulsiva e ungida a seu serviço". Quer dizer, as manifestações psíquicas são um tipo de "consciência não-espiritual que não se tem extinguido no homem maduro, senão que subsiste no transfundo de sua consciência espiritual e, em ocasiões, irrompe eruptivamente, atravessando a ordenação objetiva do espírito" (Hartmann, 1954, p. 130).

Hartmann tinha dois grandes propósitos ao enfatizar esta divisão quadripartida dos estratos do mundo real. O primeiro seria elaborar uma macroteoria dos estratos do real, isto é, construir uma "imagem da estratificação do mundo", de maneira a tornar evidente a superposição dos quatro grandes estratos, quer dizer, tornar evidente as relações de dependência e independência entre eles $^{9}$. Ao examinarmos os quatro níveis, percebemos que eles têm por objeto as "diferenças correntes que são tão bem conhecidas do pensar prático da vida diária como do pensar crítico da ciência”. Quer dizer, não se trata de uma subsunção lógica de camadas do conhecimento, isto é, de uma divisão meramente epistemológica, mas da divisão real das camadas do mundo e suas leis ontológicas de funcionamento. Cada camada tem seu próprio território soberano, e neste território, suas leis de funcionamento. Talvez, a ima-

\footnotetext{
${ }^{9}$ Em verdade, as leis relacionais entre os quatro estratos são avaliadas segundo outros critérios que não nos seria produtivo aqui examinar em pormenor (coerência, vinculação categorial etc.). Para os fins a que nos propomos, basta-nos apontar o problema das relações de independência ou dependência entre as camadas do mundo real.
} 
gem diagramática que Hartmann desenhou fosse mais correta se assumisse a forma de um conjunto - o mundo inorgânico - no qual estivessem subsumidos os demais subconjuntos, cada um subsumido ao outro em sucessão centrípeta. Ele afirma que os limites entre as camadas não estão de maneira alguma "traçados com rigor em todas as partes, pois há domínios de objetos que contém em si vários estratos (por exemplo, os da antropologia, etnologia, ciências sociais e outros), mas, por outro lado, são estes limites, ali onde ressaltam, intransponíveis" (Hartmann, 1939, p. 220). Em virtude deste caráter transitivo (porém, não-transigente) das leis que regem as camadas, torna-se extremamente difícil conceber uma "imagem total da ciência de nosso tempo", permanecendo esta imagem "fragmentária".

Daí surge o segundo propósito de Hartmann: construir uma imagem total da fábrica do mundo real a partir da demonstração da superposição relacional dos seus estratos; expor os fundamentos holísticos que permitem o trânsito do orgânico para o inorgânico, do material para o espiritual, do antropológico para o histórico. Vale à pena recorrermos aos termos do próprio Hartmann para esclarecermos este ponto referente às estruturas categoriais do ser. Segundo o autor da Ontologia.

Sua unidade [do mundo e seus quatro estratos] não é a unidade da uniformidade, senão a unidade da superposição e sobrepujamento de multiplicidades diversamente conformadas. Estas se fazem, por sua vez, colocadas umas em relação às outras de tal forma que, aquelas de tipo inferior e tosco são também as básicas e sustentantes, enquanto as superiores, descansando nas anteriores, se elevam sobre elas. Assim se eleva a natureza orgânica sobre a inorgânica. Aquela não flutua livre por si, senão que supõe as condições e leis do material físico, descansando nelas, embora elas não bastem, em absoluto, para constituir o vivente. Igualmente estão condicionados o ser psíquico e a consciência pelo organismo sustentante, unicamente no qual e com o qual aparecem no mundo. Não de outra forma, permanecem ligados os grandes fenômenos históricos da vida do espírito e da vida psíquica dos indivíduos que são seus portadores em cada caso [...]. De estrato em estrato, passando por cima de cada corte, encontramos a mesma relação, o descansar num e 
no outro, o estar condicionados "desde baixo", e, por sua vez, o ser independente, em sua conformidade e leis próprias no qual descansa o outro. (Hartmann, 1939, p. 220)

Para Hartmann, o mundo real é uno na relação que se estabelece entre os estratos e seus subníveis de heterogeneidade e multiplicidade. Cada um dos estratos tem dentro de si outros graus, como no caso do reino orgânico, subdividido em espécie, gênero, família, reino, filo, ordem e classe ${ }^{10}$. Como afirma, este mundo "tem a unidade de um sistema, mas o sistema é um sistema de estratos", e estes estão articulados numa "relação total". Os estratos e subestratos se distinguem por um "hiato" ou pela "diversidade das categorias instauradas por ele", isto é, cada um é possuidor de uma certa "substantividade", mas, também está articulado numa relação de dependência ao estrato inferior que o sustenta.

Esta digressão à macroteoria dos estratos do real de Hartmann é-nos importante porque ela posiciona o conceito gehleniano das ações de descarga como uma tentativa de constituir um princípio exclusivamente humano cujo funcionamento in vivo evidencia o fluxo entre os estratos do mundo real. As ações de descarga enquanto categoria especial da antropobiologia - devem ser concebidas como uma energia transoperacional e transorgânica das ações psicossomáticas do homem, isto é, devem ser concebidas como uma categoria de livre trânsito entre o mundo espiritual e o mundo psíquico, fluindo em mão dupla de lá para cá e daqui para lá.

A ambição de Gehlen, neste aspecto, chega aos limites do desarrazoado. Para ele, uma teoria da posição especial do homem deveria ser precedida por outra que explicasse a origem da vida, na passagem do inorgânico para o orgânico, não como evolução, mas

\footnotetext{
${ }^{10}$ A subdivisão dos estratos do mundo orgânico é tratada no penúltimo e no último volumes da Ontologia, isto é, os volumes IV e V. Hartmann divide o mundo orgânico em quatro grupos: "(i) O complexo orgânico, (ii) a vida supraindividual, (iii) a filogênese e (iv) a predeterminação orgânica". Cf. Hartmann, 1986b, p. 6-7.
} 
como criação, uma vez que o conhecimento desta passagem está sob o monopólio de um Deus Absconditus. A ciência não pode revelar a origem, mas tão-somente os mecanismos da vida. Esta seria a centelha prometeica com a qual Gehlen poderia apreender e organizar o conjunto das condições improváveis a partir das quais a natureza inorgânica deu origem à natureza orgânica. Só assim, a teoria da posição especial do homem teria "dignidade ontológica" (Gehlen, 1980, p. 77). Vejamos o que ele afirma acerca desta questão:

A antropologia pode fornecer, creio eu, uma série de categorias especiais. Entre elas, especialmente, aquelas que têm um grande interesse porque transcorrem através de várias camadas. Assim, por exemplo, com a ajuda da categoria da "descarga" podemos descrever uma das leis fundamentais da vida sensorial e motora que delimita o "campo de jogo" para a aparição da consciência pensante. Podemos inclusive mostrar essa categoria da descarga em uma atividade autenticamente espiritual, a saber, o desenvolvimento da linguagem. Poderíamos segui-la também até embaixo, até o biológico; captá-la no "reflexo condicionado". (Gehlen, 1980, p. 76-77)

O caráter transoperacional e transorgânico da categoria da descarga só pode explicar os mecanismos das operações humanas, não pode explicar a origem da vida. Está subentendido aqui o caráter intersticial das ações de descarga: ora enquanto uma energia vital do corpo que age para a sobrevivência, ora enquanto expressão da consciência pensante que opera asceticamente ante os impulsos. Embora estejam situadas neste interstício, as ações de descarga devem ser entendidas primeiramente como originárias da consciência pensante, uma vez que esta, enquanto operação humana, é uma ação que visa o prolongamento da vida. Contudo, esta consciência é débil diante da magnitude e perfeição que observamos nos processos vitais dos organismos.

Gehlen passa a se concentrar, neste aspecto, na impossibilidade de apreensão da inteligência da teleoconformidade do acontecer orgânico dos seres vivos, aquilo que por vezes denominam "obscu- 
ridade vegetativa" do organismo. As realizações vegetativas e motrizes da vida orgânica são extremamente complexas e perfeitas, entretanto a consciência desconhece completamente a dinâmica destas realizações. Os processos orgânico-corporais são inconscientes e insondáveis em sua gênese, sobretudo porque o organismo tem uma inteligência cujos processos são arcanos e autônomos.

[...] não nos tem sido dada "a explicação da possibilidade de um ente da natureza"; somente se nos tem permitido "tratar" acerca dela. [...] [há] uma faculdade mais elevada do conhecimento que não nos é própria, o intellectus archetypus. Quer dizer, uma razão produtiva e que contempla o surgimento de seus produtos já em sua gênese. É este tipo de razão que deveríamos ter para poder compreender a finalidade interna de um organismo. (Gehlen, 1980, p. 80)

A consciência, enquanto coordenação e conscientização das impressões, é a operação humana mais alijada do centro biológico do organismo. Quer dizer, todos os processos inteligentes ou autônomos que o organismo desencadeia (a regeneração, a metástase, a cissiparidade, a adaptação morfológica etc.) são processos autônomos que ocorrem ao largo da vontade consciente. Numa palavra, a consciência não pode conhecer a força vital oculta dos processos interiores, tampouco pode interferir neles. Apesar disso, a consciência deve ser entendida antes de tudo como "uma ajuda a serviço da perfeição do processo orgânico. Portanto, por essência, não é capaz de conhecer esse processo, tampouco está destinada a isso" (Gehlen, 1980, p. 81). Como afirma Gehlen, sabemos muito pouco sobre "como respiramos", "como digerimos", "como vemos e pensamos" e "como fazemos para levantar o braço".

\section{Conclusão}

A lei de descarga, portanto, significa que, em decorrência da insuficiência vital e morfológica da constituição humana, este ser débil, único na ordem regular da physis, desenvolve capacidades 
operacionais que compensam suas deficiências de maneira tal que a compensação não apenas gera uma suficiência operacionalmente equivalente aos demais animais, mais do que isso, ela produz uma sobreficiência, isto é, um plus de operacionalidade igualmente único na ordem regular da physis. O que a natureza subtrai com uma mão, compensa com a outra. Neste aspecto, as operações humanas se constituem, elas mesmas, o plus operacional que permite a sobrevivência do homem. As operações não são atividades de luxo ou conspicuidades do espírito, elas são parte da estrutura sensório-motriz que viabiliza meios para a subsistência da espécie.

Como dissemos, o fundamento da antropobiologia gehleneana é a biofilosofia dos graus do orgânico de Nicolai Hartmann. Esta substituição se torna evidente na relação da lei de descarga com a consciência. Contudo, a lei da descarga não nos provê uma explicação plausível, por exemplo, para a função fundante da violência como ação criadora de diversas instituições. Inserida no circuito da lei de descarga, a violência só pode ser concebida como uma disfunção das pulsões ou das ações de orientação, quando, em verdade, ela própria é empregada como instrumento de fabricação simbólica das instituições ordenadoras do mundo. Outro contrafacto à antropologia gehleneana diz respeito à existência do sagrado, o qual, neste modelo, encerra-se como mera "ideação simbólica", o que não ocorre na antropologia filosófica de Max Scheler. O sagrado, como bem observara Claude Lévi-Strauss, pode produzir um efeito de eficácia simbólica, de modo que a mobilidade na ordem dos estratos dar-se-ia no sentido inverso ao proposto por Hartmann, isto é, do orgânico para o espírito, e não exclusivamente do espírito para o orgânico. Por isso, reiteramos que a antropologia de Gehlen nos provê uma explicação acerca da mecânica das operações humanas, porém não uma explicação plausível acerca do simbólico e do numênico. 


\section{Referências}

ALSBERG, Paul. (1922). In quest of man: a biological approach to the problem of Man's place in Nature. Oxford; New York; Toronto; Sidney; Braunschweig: Pergamon Press, 1970. (Título original: Das Menschheitsrätsel.)

ARLT, Gehard. Antropologia filosófica. Petrópolis: Vozes, 2008.

BERGSON, H. A evolução criadora. Trad. Adolfo Casais Monteiro. São Paulo: Unesp, 2009.

BOLK, Louis. Le problème de la genèse humaine. Revue française de psychanalyse. v. 25, n. 2, 1961, p. 243-279.

BUYTENDIJK, F. J. J. Psychologie des Animaux. Paris: Payot, 1928.

BUYTENDIJK, F.J.J. O homem e o animal: ensaio de psicologia comparada. Lisboa: Livros do Brasil, [s.d.].

DARWIN, Charles. A origem do homem e a seleção sexual. Lisboa: Relógio D’Água, 2009.

DRIESCH, Hans. The history and theory of vitalism. London: Macmillan, 1914.

EIBL-EIBESFELDT, Irenäus. Human Ethology. New York: A. de Gruyter, 1989.

FISCHER, Joaquim. Philosophische Anthropologie: eine Denkrichtung des 20. Jahrhunderts. München: K. Alber Freiburg, 2009.

GEHLEN, Arnold. (1940). El hombre: su naturaleza e su lugar en el mundo. 2. ed. Salamanca: Sígueme, 1980.

GEHLEN, Arnold. Man: his nature and place in the world. New York: Columbia University Press, 1988. Introdução de Karl-Siegbert Rehberg. 
GEHLEN, Arnold. Gesamtausgabe - Der Mensch. 3. ed. Teilband 1. Frankfurt: V. Klostermann, 1993.

HABERMAS, Jürgen. Perfiles filosófico-políticos. Madrid: Taurus, 1975.

HARTMANN, Nicolai. Nueva Ontologia. Buenos Aires: Sudamericana, 1954.

HARTMANN, Nicolai. Introducción a la filosofia. México: Universidade Autónoma do Mexico, 1969.

HARTMANN, Nicolai. (1939). Ontologia III. La fabrica del mundo real. México: Fondo de Cultura Económica, 1986a.

HARTMANN, Nicolai. (1950). Ontologia V. Filosofia de la Naturaleza. Teoria Especial de las Categorias. El Pensar Teleológico. México: Fondo de Cultura Económica, 1986b.

KLAGES, Ludwig. (1922). Dell'eros cosmogonico. Avellino: Edizioni di Ar, 2010.

KOHLER, Wolfgang. The mentality of apes. London: Kegan Paul, Trench, Trubner. U.S. edition by Harcourt, Brace \& World, 1925.

LEVI-STRAUSS, Claude. (1949). A eficácia simbólica. In: LEVI-STRAUSS, Claude. Antropologia Estrutural - Volume 5. Rio de Janeiro: Tempo Brasileiro, 1975.

LORENZ, Konrad. (1937). Sobre a formação do conceito de instinto. In: LORENZ, Konrad. Três ensaios sobre comportamento animal e humano. Lisboa: Arcádia, 1975a. p. 7-76.

LORENZ, Konrad. (1950). O todo e a parte na sociedade animal e humana. In: LORENZ, Konrad. Três ensaios sobre comportamento animal e humano. Lisboa: Arcádia, 1975b. p. 77-191. 
LORENZ, Konrad. (1954). Psicologia e filogénese. In: LORENZ, Konrad. Três ensaios sobre comportamento animal e humano. Lisboa: Arcádia, 1975c. p. 193-265.

MARQUARD, Odo. Sobre la historia del concepto filosófico de "Antropología" desde finales del siglo XVIII. In: MARQUARD, Odo. Dificuldades con la filosofía de la historia: ensayos. Valencia: Pré-Textos, 2007. p. 133-158/232-268.

PLESSNER, Helmuth. (1928). Die Stufen des Organischen und der Mensch: Einleitung in die philosophische Anthropologie. Berlin; New York: W. de Gruyter, 1975.

PORTMANN, Adolf. Zoologie und das Neue Bild des Menschen: biologische Fragmente zu einer Lehre vom Menschen. Hamburg: Rowohlt Hamburg, 1956.

SCHELER, Max. (1928). A posição do homem no cosmos. São Paulo: Forense Universitária, 2003.

UEXKÜLL, Jacob von. Dos animais e dos homens: digressão pelos seus próprios mundos - doutrina do significado. Lisboa: Livros do Brasil, [s.d.].

UEXKÜLL, Jacob von. Umwelt und Innenwelt der Tiere. 2. verm. u. verb. Aufl. Berlin: J. Springer, 1921.

Artigo recebido em 28/01/2016, aprovado em 1/02/2016 